\title{
ŚWIĘTOŚĆ JAKO WARTOŚĆ W XVII-WIECZNYM ŻYWOCIE ŚWIĘTECO NORBERTA
}

\section{MACIE] MĄCZYŃSKI}

\section{HOLINESS AS A VALUE IN THE SEVENTEENTH-CENTURY LIFE OF SAINT NORBERT}

\begin{abstract}
The Life of St. Norbert was founded in the Premonstratensian (Norbertan) monastery in Kraków in Zwierzyniec. As required by the species, it contains a description of the life, activity and death of the founder of the Premonstratensian order, Archbishop Magdeburg, patron of Prague. It also contains a description of the miracles that happened through his intercession and became the basis for parallel canonization. The analyzed text was intended for religious sisters to individual reading, and via this exercise became acquainted with the person of the saint patron. The educational goal of the text was also to show Norbert's holiness treated as the highest value in the Christian hierarchy. The author of the text signals Norbert's holiness in various ways. The aim of the paper was to reconstruct these methods, find them in the language layer of the text and analyze the language units and contexts in which they occurred. The article is part of the research on language axiology, it presents the name of one value, which is the highest value for Christians, especially nuns.
\end{abstract}

KEY WORDS lives of saints, language axiology, holiness as a value, old Polish CONTACT Uniwersytet Pedagogicznyw Krakowie; maciej.maczynski@up.krakow.pl 
Informacja podana w tytule Żywota ${ }^{1}$ wskazuje jednoznacznie na źródło tekstu - jest nim trzeci tom dzieła kolońskiego kartuza Wawrzyńca Saura (Suriusza), który w latach 1570-1575 wydał 6 tomów in folio i 7. tom, będący suplementem, pod wspólnym tytułem De probatis sanctorum historiis. W tomie trzecim tegoż dzieła, wydanym w Kolonii w 1572 roku, zawarty jest żywot św. Norberta, który jest obszernym streszczeniem średniowiecznego Vitae B sancti Norberti, o czym autor pisze w dodatku do żywota (s. 545) $)^{2}$. Zamieszczony w XVII-wiecznym rękopiśmiennym kodeksie, przechowywanym w klasztorze sióstr norbertanek na Zwierzyńcu (sygn. 594), tekst żywota św. Norberta jest wybiórczym tłumaczeniem Suriusza przeznaczonym dla zakonnic do indywidualnego czytania ${ }^{3}$. Lektura tekstu miała dać norbertankom istotne informacje o życiu, śmierci i cudach czynionych zarówno za życia, jak i po śmierci założyciela i patrona zakonów norbertańskich (premonstrateńskich), będącego nie tylko prawodawcą zakonu, ale także jego pierwszym opatem - ojcem. Żywot św. Norberta należy do gatunku żywotów świętych, których treść „była warunkowana przez aksjologię chrześcijańską” (Krzywy 2014: 49). Wartością (,tym, co jest dobre' Puzynina 1993: 16) nadrzędną w chrześcijaństwie jest ŚWIĘTOŚĆ, którą Encyklopedia Katolicka definiuje jako „atrybut Boga, będącego ontologicznie świętością i źródłem każdej świętości, zwłaszcza człowieka, który osiąga ją przez naśladowanie Jezusa Chrystusa, realizację cnót teologalnych oraz przestrzeganie zasad etyczno-moralnych" (2013:400). Świętość człowieka nie jest ontologiczna (J. Rodzoch-Malek 2011: 178), gdyż jest naznaczona wyborem Boga. To Bóg powołuje do świętości, człowiek zaś, by stać się świętym, musi to powołanie rozpoznać i pójść za Jego głosem. Bóg przez dotknięcie miłością uświęca człowieka i nadaje jego życiu nowy sens - jednym z jego przejawów jest czynienie dobra. Wybitna badaczka języka wartości - Jadwiga Puzynina - świętość umieszcza wśród wartości transcendentnych, dla których ustala centrum pojęciowe: dobro transcendentne i świętość właśnie. Taką wartością jest w Żywocie świętość Norberta, którą anonimowa autorka sygnalizuje na różne sposoby. Moim zadaniem jest zrekonstruowanie tych sposobów, odnalezienie ich w warstwie językowej zabytku i wskazanie jak XVII-wieczna zakonnica postrzega tę wartość w osobie założyciela i prawodawcy zgromadzenia, do którego należy i jak ją opisuje. Mam przy tym świadomość, że wartościowanie w rękopiśmiennym zabytku dokonywane jest przez zakonnicę, która świętość rozumie zgodnie z teologią katolicką jako świętość samego Boga oraz świętość Kościoła, uznaje też powołanie wszystkich chrześcijan do świętości (Zmuda 2018: 32). Dla zakonnic - adresatek analizowanego tekstu Żywota - świętość jest wartością najwyższą, bo każda z nich, wybierając klasztor, chce ją osiągnąć. W kościele katolickim święty, czyli „ogłoszony przez Kościół jako zbawiony i mogący być przedmiotem kultu” (Doroszewski SJP, 1966, t. VIII) jest traktowany jako wzór, ideał, do którego chrześcijanin winien dążyć. Tym bardziej zakonnice, które, realizując cel chrześcijańskiego życia, wybierają drogę trudną,

1 Pełny tytuł utworu brzmi: Żywot świętego Norberta Pierwszego Ojca Zakonu Premonstratensów, Arcybiskupa Magdeburskiego, pisany od jego rówiennika i klasztorom jego podany, surius tomo tertio, żył około roku pańskiego 1130.

2 O Wawrzyńcu Suriuszu i jego dziele pisze w kontekście Żywotów Piotra Skargi Henryk Fros (1991: 173). O najwcześniejszych żywotach św. Norberta zob. Knapiński (1884: 7).

3 Tekst zamieszczony w kodeksie nie jest wzorowany na żywocie św. Norberta autorstwa Piotra Skargi, różnice pomiędzy wersjami tekstu są zbyt duże, by można mówić o jakichś zależnościach. Na pierwszą połowę XVII wieku przypada aż 8 wydań dzieła Skargi i jest wielce prawdopodobne, że dzieło to znajdowało się w bibliotece klasztornej, nie mniej jednak źródło tekstu jest wyraźnie określone w tytule, a zbieżność z tekstem oryginalnym Suriusza jest dobrze widoczna. 
drogę nieustannej modlitwy i pracy w zakonie kontemplacyjnym, gdzie dodatkowo obowiązuje bezwzględne posłuszeństwo wobec przełożonych oraz równie bezwzględne silentium. Umieszczenie tekstu w kodeksie koresponduje z kolejną częścią dzieła, którą stanowi ośmiopunktowe Rozmyślanie przez oktawę S. Norberta z żywota jego. Autorka Rozmyślania przywołuje opisane w Żywocie wydarzenia i na ich kanwie buduje rozmyślania (medytacje) przeznaczone dla zakonnic ${ }^{4}$.

\section{1/ ŚWIĘTOŚĆ PRZEZ NAZYWANIE}

W Żywocie świętego Norberta leksem świętość nie wystąpił ani razu ${ }^{5}$. Nieobecność tego wyrazu w badanym tekście być może należy tłumaczyć jego niską frekwencją w staro- i średniopolszczyźnie. Oba wyrazy - świętość i święty - należą do najstarszej warstwy słownictwa, oba wystąpiły w najstarszej części Psałterza floriańskiego powstałej przed rokiem 1400, ale na przykład przymiotnik święty w wydanej po raz pierwszy w 1599 roku Biblii ks. Jakuba Wujka wystąpił w 128 wersetach, podczas gdy pochodna od niego nazwa cechy abstrakcyjnej - świętość tylko raz ${ }^{6}$. W tekście żywota - świętość Norberta zakonnica oddaje, za pomocą leksemu święty będącego przydawką przymiotną określającą imię własne. Imię założyciela Premonstratensów bez owej przydawki pojawia się w zabytku zaledwie kilka razy i nie jest nacechowane aksjologicznie, np.: Gdy tedy Norbert był wydany na świat; Norbert ku przyjęciu święcenia (...) odzienie swe złotem i perłami lśniące, w którym świata zażywał zewlókt7. Imię z przydawką: Norbert święty jest zdecydowanie częstsze. Postpozycyjny szyk przydawki jest w tekście zakłócony jednym przypadkiem szyku prepozycyjnego, który wystąpił tylko w tytule dzieła: Żywot świętego Norberta. Taki szyk jest zgodny nie tylko z łacińskim pierwowzorem Vita sancti Norberti, ale także z wieloma tytułami średniowiecznych vitae. Świętość Norberta ${ }^{8}$, dająca prawo do tytułowania go przymiotnikiem

4 Tytuły poszczególnych części rozmyślań: O niezmiernej dobroci Boskiej nad grzesznymi; O powołaniu S. Norberta; O dziwnej odmianie Ojca s. Norberta; O tym co Pan Bóg odpowiada Norbertowi świętemu o strzeżeniu się grzechu; O pokoju, który zaleca Pan Bóg świętemu Norbertowi; O pokorze świętej i ubóstwie Norberta świętego; O szczerej mitości Bożej i inszych cnotach Ojca s. Norberta; O zacności Zakonu świętego Premonstrateńskiego

5 Brak tego leksemu w XVII-wiecznych rozmyślaniach dla nowicjuszek w klasztorze benedyktynek zauważyła Ewa Zmuda (2018:33).

6 Dane te przytaczam na podstawie biblii internetowej https://biblia.apogoletyka.com/read, dostęp 17.11.2019. W Biblii Tysiąclecia przymiotnik święty notowany jest w 121 wersetach, leksem świętość tylko w 15 i to głównie w Starym Testamencie w odniesieniu do Boga. W Nowym Testamencie wyraz wystąpił tylko raz $(1$ Kor 7,14$)$ i odnosi się do niewierzącej żony, która uświęca się przez wierzącego brata.

7 Cytaty z tekstu żywota podaję w pisowni oryginalnej, wprowadzam współcześnie obowiązujące znaki diakrytyczne i interpunkcję.

8 Arcybiskup Magdeburga Norbert jest zaliczony w poczet świętych Kościoła Katolickiego na mocy dwóch dyplomów papieża Grzegorza XIII. W pierwszym, z dnia 28 lipca 1582 r., ustanawiał święto Norberta na 6 czerwca, w drugim, z 15 sierpnia 1582, ustanawiał na ten dzień odpusty w kościołach norbertańskich. Dodatkowo papież Grzegorz XV 7 września 1621 roku zatwierdził lekcje drugiego nokturnu w Brewiarzu Rzymskim i dokonał kanonizacji równoważnej, a Klemens X dekretem z 7 września 1672 podniósł święto Norberta do rzędu duplex dla całego kościoła (zob. Knapiński 1885: 325-326). Święto duplex to święto zdwojone, w którym już od średniowiecza odmawiano dwa oficja - jedno z dnia powszedniego, drugie ze święta. Przez oficjum należy rozumieć tu liturgię godzin (Officium divinum) - publiczną modlitwę kościoła realizowaną jako zalecenie św. Pawła wyrażone np. w pierwszym Liście do Tessaloniczan $(5,17)$ by „nieustannie się modlić” (zob. KKK 1994: 289). 
święty, jest usankcjonowana dyplomem papieskim i potwierdzona nie tradycyjnym procesem kanonizacyjnym, lecz mocą tzw. kanonizacji równoważnej`.

Przymiotnik święty pojawia się w tekście Żywota również w kolokacji mąż święty, co jest tłumaczeniem obecnego w łacińskim oryginale vir sanctus, np.: Mąż święty pokornie i mądrze odpowiedziat; Tam przeszkadzat [czart] braciej ale na przyjście Męża Świętego odpędzony był (...). W kolejnej kolokacji z przymiotnikiem święty - ojciec święty - ojcostwo Norberta odnosi się do współbraci. Norbert jest ojcem, gdyż, będąc założycielem zgromadzenia i jego pierwszym opatem generalnym, stał się opatem - ojcem, któremu podlegają wszyscy zakonnicy. Święte ojcostwo oparte na doskonałej miłości uzdalnia do czynienia cudów: Tegoż czasu, gdy [Norbert] niektórego brata chciat obrać na negotia klasztorne znalazł febrę cierpiacego, naznaczył mu w imię Chrystusowe i moca posłuszeństwa, idź powiada, a wróć się i już więcej nie cierp tej febry. Na te słowa ozdrowiat i wypetnił mandat ojcowski.

Bliskie świętości jest określenie łacińskie vir Dei, którym wielokrotnie nazywa się Norberta w łacińskim tekście Żywota, a które autorka omawianego zabytku oddaje wierną oryginałowi kolokacją mąż Boży, np.: Co Mąż Boży otrzymawszy z wielką dufnością z bosemi nogami na połaci i wszędzie Ewangelie opowiadał (...). Mąż Boży to określenie starotestamentowe, stosowane na nazwanie: Mojżesza (Pwt 33,1) ${ }^{10}$, anioła posłanego przez Boga $(\mathrm{Sdz} 13,6)$ oraz proroków, którzy są głosem Boga (1Sm 9,6). W pierwszej Księdze Samuela mąż Boży został scharakteryzowany jako: „człowiek poważny: co powie, wszystko się staje“. Św. Norbert w Żywocie jest przedstawiony jako człowiek mający szczególny kontakt z Bogiem. Bóg pozwala mu widzieć przyszłość: A Norbert Święty $w$ Kampembergenskim klasztorze bracią do trwałości upominat, którym gtód $w$ Westfalii przyszły opowiadat, co się stało, bo przydało się jednego czasu, że bracia do obiadu chleba nic nie mieli. Bóg mówi do niego i odpowiada na jego pytania: Norbercie, Norbercie, co czynisz. Twardo jest przeciw ościeniowi wierzgać. Słowa Boga są przyczyną konwersji Norberta: I jakoby usłyszał głos do siebie mówiący: Przestań od złego a czyń dobre, szukaj pokoju a przenaśladujgo. Być mężem Bożym to - w rozumieniu XVII-wiecznej zakonnicy - być z Bogiem w szczególnej, uświęconej relacji właściwej ludziom świętym. To oni stają się pośrednikami pomiędzy wiernymi a Bogiem, a cześć im oddawana (veneratio sanctorum) przechodzi na samego Boga, sprawcę ich świętości.

\section{2 / ŚWIĘTOŚĆ PRZEZ NAŚLADOWANIE}

Autorka Żywota używa leksemu święty w znaczeniu wypływającym z głębokiej wiary. Drogą do świętości jest naśladowanie Chrystusa ${ }^{11}$ prowadzące wierzącego do doskonałej miłości. Taką drogą kroczył św. Norbert: przyszedt do Federika Arcybiskupa i jemu wszystkie swoje myśli powiedziat o naśladowaniu Chrystusa. Zalecał je też swoim współbraciom: Zaraz też w dzień Narodzenia Bożego

9 Kanonizacja równoważna to orzeczenie o świętości wyrażone nie „w zwykłej formule kanonizacji, lecz w dekrecie zobowiązującym cały Kościół do oddawania czci danemu słudze Bożemu i otaczania go takim samym kultem, jaki należy się świętym kanonizowanym" (www.opoka.org, dostęp 17.11.2019).

10 Wszystkie cytaty biblijne i skróty nazw ksiąg pochodzą z: Pismo Święte Starego i Nowego Testamentu $w$ przekładzie z języków oryginalnych. Opracował zespót biblistów polskich z inicjatywy benedyktynów tynieckich, Warszawa 1980, wyd. III poprawione.

11 O naśladowaniu Chrystusa prowadzącym do świętości zob. m.in. św Paweł (Ef. 5, 1-2): „Bądźcie więc naśladowcami Boga, jako dzieci umiłowane, i postępujcie drogą miłości, bo i Chrystus was umiłował i samego siebie wydał za nas w ofierze." 
roku 1119 każdy z nich podpisali się i przysiegli pod ta Reguła i potem wiele z nich przystawało na wojne duchowna, których do pokory świętej napominat (...) i upominat Chrystusa swego naśladować. Nawołując współbraci do wzorowania się na Chrystusie, stawiał przed nimi zadania trudne, chciał by zachowywali całkowity post rozumiany jako powstrzymanie się od potraw mięsnych: Chciał też aby bracia jego postanowienia na wszelki czas oprócz choroby mięsa nie jadali. Zalecana asceza dotyczyła także ubioru: na ciele nie mieć płótna nijakiego, gdyż on [sam] włosiennice używał; przywodzit bracia, aby w starym i podtym odzieniu kochali się i często do nowych szat stare platy przyszywali. Przede wszystkim zaś żądał od współbraci pokory: do pokory świętej [ich] napominat. Można przyjąć iż, zalecając zakonnikom pokorę, miał na myśli ,poczucie własnej niższości, małość' w stosunku do Boga (Grzegorczykowa 1993: 31), natomiast w stosunku do człowieka pokora miała skutkować pełnym poświęcenia oddaniem. Oddanie Chrystusowi realizowane w naśladowaniu najpełniej oddają słowa zamieszczone w Żywocie: słowy i uczynkami wolat nic nie umieć jeno Chrystusa Jezusa, tegoż ukrzyżowanego. Św. Norbert naśladuje Chrystusa także w miłości bliźniego - spełnia tym samym przykazanie Jezusa „abyście się wzajemnie miłowali, tak jak Ja was umiłowałem” (J 13,34).

\section{3 / ŚWIĘTOŚĆ PRZEZ MIŁOŚĆ DO BOCA I BLIŹNIECO}

Miłość Norberta do Boga dla autorki tekstu była oczywista, nie wymagała opisu, zaświadcza ją w zasadzie cały tekst Żywota. Dla tej miłości Norbert porzuca świeckie, wystawne życie, obiera trudne życie zakonne, przyjmuje odpowiedzialną funkcję arcybiskupa Magdeburga, by krzewić i umacniać wiarę, wzmacniać Kościół, głosić wiernym Słowo (Norbert pełnił nadaną mu przez papieża Gelazjusza II funkcję wędrownego kaznodziei). W jednym tylko miejscu pojawia się zapis: Albowiem takowa była wiara i miłość ku Panu Bogu, iż żadne fatygi cielesne nie zaszkodzity $m u, w$ którym o miłości do Boga świadczą codzienne umartwienia. Równie ważna w świętości jest miłość do bliźniego, wyrażona w nowym przykazaniu Jezusa. Realizując tę miłość w swoim zgromadzeniu, Norbert żywi ubogich: Norbert święty jachat z nim pożegnając się z bracią i zostawiwszy im pieniędzy któremi żywił sto i dwadzieścia ubogich, co i po dziś dzień jest wiecznymi czasy. Rozdaje im swój majątek: Udał się na peregrynacje, przykładem Abrahama Patryjarchy, $z$ dwiema towarzyszami, te pieniądze, które miat ubogim rozdat w drodze; ojczyznę swoją ubogim rozdat, nic sobie nie zostawiając. Pozbywa się majątku kościelnego: wszystkie dobrodziejstwa kościelne które trzymał Arcybiskupowi spuścit. Powodowany miłością bliźniego prowadzi wiernych do zbawienia: $W$ ten czas dopiero począ ciężej pracować około zbawienia ludzkiego, poganów srogich nic się nie lękając. Drogą zbawienia prowadzi wszystkich: on dobrych miłując, złych nie przestat karać aż się uznali.

\section{4 / ŚWIĘTOŚĆ PRZEZ CUDA}

Świętości Norberta dowodzą cuda, jakie opisano w Żywocie. Jak wiadomo cudem w teologii są zdarzenia niemające racjonalnego wyjaśnienia, niedające się objaśnić powszechnymi prawami natury, przez co uznawane są za ingerencję Boga. Cuda są wskazaniem na Boga, na Jego wszechmoc „dla Boga bowiem nie ma nic niemożliwego" (Łk 1,37) i ze względu na swoje boskie źródło należą do świętości. Tak więc człowiek święty, dokonując cudu dla dobra ludzi, umacnia wiarę w Boga. Cudem, który zaowocował umocnieniem wiary, było uzdrowienie ociemniałej: Po mszy świętej niewiasta jedna tchnieniem jego wzrok odniosła, którym cudem ludzie zacni zwruszeni 
samych siebie i rzeczy swoje przez ręce Norberta Świętego Bogu ofiarowali. Kolejnym - rozmnożenie chleba: Przydało się jednego czasu, że bracia do obiadu chleba nie mieli i nigdzie dostać nie mogąc Mą̇̇ Boży stowa one wspominat (...) Nie zagubi Pan głodem dusze sprawiedliwego, a oto z prędka Pan dostatek chleba braciej przystat, iż sami i przychodniowie dosyć go mieli, od tego czasu na niczym im nie zbywato.

Anonimowa norbertanka - za XII-wiecznym autorem Vitae B, przytaczając szczegółowe opisy, podkreśla bożą moc Norberta. Żywot opisuje czterokrotne zwycięstwo Norberta nad szatanem. W jednym z takich opisów autorka dostrzega, iż takie zwycięstwo było możliwe dzięki posiadaniu przez Norberta bożej mocy: Jednej nocy nie spał, przed ottarzem klęcząc w sacelle swej, stanąt wedle niego szatan w osobie niedźwiedzia, zębami i paznokciami miotając się na Norberta Świętego, zląkt się wprawdzie naprzód, ale zaraz poznawszy sidła szatańskie, Bożą mocą odegnał go. Owa boża moc pozwoliła Norbertowi zwalczyć uosabiane przez szatana siły zła: Lecie w wielka goracość przyniesiono pragnącym wody, w której na ksztatt żaby czart ukazat sie, odkrywając zdradę jego Mąż Boży rzecze: wyrzućcie go, bo większa jest jego chytrość niż moc. Tam przeszkadzał bardzo braciej, ale na przyjście Męża Świętego odpędzony byt, gdyż i bestie leśne na kiwnienie Męża Bożego zaniechały srogości swojej.

Cuda, które wydarzyły się po śmierci Norberta, potwierdzają jego świętość: Ciało jego przez wiele dni nie było pogrzebione dla sporu, który był między kanonikami katedralnego kościoła i kanonikami Panny Marii o miejsce pogrzebu jego, urosły wielkie gorąca, nieskażone zostało, potem z rozkazania Lotariusza Cesarza przed ołtarzem Świętego Krzyża u Panny Marii pogrzebione jest. Idzie w tym zapisie o Owo nieskażenie ciała trzeba rozumieć jako trwałość zwłok świętego (niepodleganie rozkładowi), co współcześnie nie jest warunkiem koniecznym do kanonizacji, ale znacznie proces kanonizacyjny przyśpieszającym. Jako cudowne traktuje Żywot pośmiertne ukazanie się Norberta współbraciom: Tegoż dnia i godziny, której Mąż święty z tego świata zszedł, jednemu z braci ukazał się w ślicznej szacie, gałązkę oliwną w ręku niosąc, który gdy spytał skąd przyszedł i dokąd idzie, z raju powiada posłany jestem, skąd tę gałązkę kwitnącą przyniosłem i idę abym na miejscu ubóstwa mego, to jest w Premonstrateńskim kościele wszczepił ją. Drugiemu też bratu ukazał się w własnej postaci, ale zaraz osoba przemieniła się w kwiat bardzo śliczny, którego Anieli wziąwszy do nieba zanieśli.

\section{5 / ŚWIĘTOŚĆĆ PRZEZ KONTAKT Z SACRUM}

O świętości Norberta świadczą te fragmenty tekstu, w których zakonnica opisuje jego kontakty z osobami należącymi do sfery sacrum. Objawienia te zawsze poprzedza gorąca modlitwa Norberta, niekiedy wzmocniona postem: udat się na modlitwę i posty z tymi, którzy chodzili na kazanie, prosząc Pana Boga aby raczył objawić ciała męczenników i panien świętych. Modlitwa zostaje wysłuchana, święci przybywają z pomocą. Św. Urszula i jej towarzyszki pomagają odnaleźć swoje święte ciała: Ukazała się tedy jedna Panna zjedynaście tysiąc dziewic, niektóre mu w nocy objawiają imie i miejsce gdzie leży, które rano zupetnie naleziono. Modlitwa pomaga też odnaleźć miejsce pochówku świętego Gerona: Nazajutrz mąż Boży świętego Gerona męczennika ciało zupetne nalazł, z weselem wielkim wziąt część Mąż Boży a inne części z wielkq̨ uczciwością od duchownych pochowano. W innym miejscu badanego tekstu Norbertowi objawia się Matka Najświętsza: Oto bowiem Panna Maryja ukazuje mu się obłóczona z chórami anielskimi, oznajmując mu, iż wysłuchane sq modlitwy twoje i miejsce gdzie głowa zakonu jego będzie pokazuje. Habit także nakazuje, w którym ma być obleczony, mówiąc do niego te słowa: Synu weźmi śliczną szatę. Wreszcie św. Augustyn osobiście wręcza Norbertowi 
regułę klasztorną: ukazat się Mężowi Bożemu Augustyn Święty, który i regułę złotą podał mu samego siebie oznajmując mu rzekt: Ja jestem Augustyn niegdy Biskup Hiponenski, oto masz regute, która pisałem, pod która, jeśli dobrze będą walczyć bracia twoi, synowie moi, bezpieczni z Chrystusem stana na ostatnim sądzie. Opisywane objawienia umacniają wiarę w świętość Norberta. Maryja i inni święci przychodzą Norbertowi z pomocą, ale pomoc ta skierowana jest za jego pośrednictwem na tych, których skupił w założonym przez siebie zgromadzeniu.

\section{6 / UWAGI KOŃCOWE}

W Żywocie świętego Norberta anonimowa autorka postrzega świętość Norberta jako wartość istotną dla całego zgromadzenia. Ma to być bowiem cel, do którego powinna dążyć każda zakonnica. Wartość ta ukazywana jest poprzez nazywanie tj. nominację dokonywaną za pomocą nazwy własnej z dookreślającą przydawką przymiotną święty oraz za pomocą deskrypcji określonych, czyli grup językowych, które ze względu na kontekst, jednoznacznie wskazują na osobę Norberta. Innym sposobem ukazywania świętości jest orzekanie o faktach z życia Norberta, na podstawie których autorka określa jego stosunek do Boga i bliźniego, jego religijność, czy skuteczność kontaktów z sacrum.

Świętość, jak wiadomo, jest nierozerwalnie związana z Bogiem. To o sobie mówi Bóg: „Bogiem jestem, nie człowiekiem; pośrodku ciebie jestem Ja-Święty” (Oz 11,9). Świętość jest dla chrześcijan wartością najwyższą, gdyż jej źródłem jest miłość doskonała - Jezus Chrystus. Człowiek przez naśladowanie ziemskiego przebywania Boga, może ją osiągnąćc ${ }^{12}$. O świętości rozumianej jako „wyniesienie na ołtarze” decydują ludzie - dzisiaj w trudnym, wieloetapowym procesie kanonizacyjnym, prowadzonym według bardzo surowych reguł. To człowiek, rekonstruując życie kandydata do świętości, musi odpowiedzieć na szereg istotnych pytań o świętość właśnie, o to, czy to, co prawdziwie boskie było widoczne w jego życiu.

Żywot św. Norberta pokazuje wyraźnie, iż to, co boskie, było obecne w życiu świętego i działa po jego śmierci. „Moc uzyskana przez świętych nie gaśnie z ich zgonem - pisze Zofia Kossak-Szczucka - Niezniszczalna, wciąż aktywna, wciąż promieniująca, stanowi złoże energii silniejszej niż atomowa, zdolnej przeobrazić świat" (1958: 146). Moc świętości Norberta powodowała, iż jeszcze za życia świętego klasztory premonstrateńskie powstawały w całej Europie. Z uświęconych wizji Norberta zakonnicy czerpali wiarę, którą - jak pisze autorka Żywota - szerzyli (lśnili) w różnych stronach świata: Ale Norbert Święty Panu Bogu się modląc, ukazał się widomie na tym miejscu, gdzie dziś kościół premonstrateński postawiony jest, Chrystus na krzyżu wiszaccy, nad którym siedm promieniów słonecznych dziwnej jasności świętej, widzieli też z czterech części świata niezliczonq wielkość pielgrzymów świętych skłaniających się do niego, którzy jakoby pokłon uczyniwszy swemu odkupicielowi i nogi jego pocałowawszy jakoby wolność biorąc na rozmaite strony lśnieć zwracali się. Moc świętości Norberta owocowała łaskami Boga: Zwróciwszy się do Premonstratu [Norbert] kościót w Laudunie Marcina świętego potwierdzit, który za Galerta opata postawit, któremu dał Pan Bóg taka łaskę przez błogosławienstwo Norberta świętego (...) ten Galertus we dwanaście lat więcej niźli pięćset braci tam zgromadził i Pan Bóg wszystko rozmanażał. Moc ta musiała być duża także po śmierci

12 „Ten, kto wierzy w Chrystusa staje się synem Bożym. To przybrane synostwo przemienia go, pozwalając mu iść za przykładem Chrystusa; uzdalnia go do prawego działania i do czynienia dobra. W zjednoczeniu ze swoim Zbawicielem uczeń osiąga doskonałość miłości - świętość" (KKK 1994: 407). 
skoro, jak podają źródła historyczne, według spisu z roku $1320 \mathrm{w}$ Europie w tamtym czasie istniało około 449 klasztorów norbertańskich ${ }^{13}$. Mimo, iż reguła zakonna należała do bardzo surowych, nowe fundacje (także w Polsce) przyciągały rzesze zakonników, którzy po złożeniu ślubów przyjmowali trudne obowiązki nałożone Statutami. Dla tych, którzy - wzorem swojego założyciela i patrona - wybrali uświęcone życie zakonne, świętość jest wartością, bo jest wypełnieniem woli Boga: Bądźcie świętymi, bo Ja jestem święty - wzywa Bóg (KP€ 11,4). Na to wezwanie odpowiedział św. Norbert, a jego drogę do świętości zapisano w tekście Żywota.

\section{HOLINESS AS A VALUE IN THE SEVENTEENTH-CENTURY LIFE OF SAINT NORBERT}

SUMMARY An analysis of the manuscript The Life of St. Norbert, whose aim was to reconstruct the linguistic ways of expressing holiness, showed that holiness, for both the author of the text and its addressees - nuns from the Premonstratensian monastery, is the supreme value. Its source is faith, and the Christian's duty is to strive for it. The holiness of the founder of the congregation and patron of the nuns on plane of the text is expressed by: proper name specified by attributive saint and collocations: holy husband, holy father, husband of God, which are synonymous definite descriptions. The analysis of the text also helped to reveal those ways of signaling Norbert's holiness, which the author expressed in syntactic structures (sentences). These were sentences describing Norbert's pursuit of holiness by imitating Christ, indicating his love for God and neighbor, describing his special contact with the sacred. Considering the educational purpose of the text, the author made detailed descriptions of the miracles that took place both during the lifetime and after the death of St. Norbert, presenting them as a firm confirmation of his holiness. Norbert's holiness was a source of faith for Premonstratensians and inspired new monastery foundations.

\section{LITERATURA}

I Encyklopedia katolicka, 2013, T. 18 Serbowie - Szczepański, red. nacz. E. Gigilewicz, Lublin.

I Fros H., 1991, Źródła „Żywotów świętych” Piotra Skargi, „Pamiętnik Literacki“, LXXXII, z. 3, s. $173-194$.

I Grzegorczykowa R., 1993, Pokora, pycha i pojęcia pokrewne. Nazwy wartości. Studia leksykalno-semantyczne, red. J. Bartmiński, M. Mazurkiewicz-Brzozowska, Lublin.

I Katechizm Kościoła Katolickiego (KKK), 1994, Poznań.

I Knapiński W., ks. 1884, Święty Norbert i jego zakon. Początki norbertańskich zakonów w cyrkarii polskiej i nieco z ich dziejów, Warszawa, nakładem wydawcy Encyklopedii Kościelnej.

I Kossak-Szczucka Z., 1958, Rok polski. Obyczaj i wiara.

13 Liczba ta w różnych zestawieniach jest różna, dlatego dane te należy traktować jako orientacyjne (zob. Knapiński 1884: 60) 
I Krzywy R., 2014, Poezja staropolska wobec genologii retorycznej. Wprowadzenie do problematyki, Warszawa.

I Pismo Święte Starego i Nowego Testamentu w przekładzie zjęzyków oryginalnych. Opracował zespót biblistów polskich z inicjatywy benedyktynów tynieckich, 1980, Warszawa, wyd. III poprawione.

I Puzynina J., 1993, Język wartości, Warszawa.

I Rodzoch-Malek J., 2011, Wieczne państwa świętego z doczesnym zatargi. Święty i świętość. Humanizm w języku polskim. Wartości humanistyczne w polskiej leksyce i refleksji o języku, red. A. Janowska (i in.), Warszawa, s. 175-233.

I Stownikjęzyka polskiego, 1958-1969, red. W. Doroszewski, Warszawa.

I Zmuda E., 2018, „....abym zrzuciwszy z siebie człowieka świeckiego z nałogami iego, stała się prawdziwie duchowną i świętą". Świętość zakonnicy w świetle leksyki rozmyślań dla nowicjuszek- benedyktynek. Święci i świętość w języku, literaturze i kulturze, red. H. Leleń i T. Żurawlew, Kraków, s. 31-45. 